\title{
NHEJ1 wt Allele
}

National Cancer Institute

\section{Source}

National Cancer Institute. NHE/1 wt Allele. NCI Thesaurus. Code C88514.

Human NHEJ1 wild-type allele is located in the vicinity of $2 \mathrm{q} 35$ and is approximately $85 \mathrm{~kb}$ in length. This allele, which encodes nonhomologous end-joining factor 1 protein, plays a role in the mediation of both $\mathrm{V}(\mathrm{D})$ J recombination and the repair of damaged DNA. Mutation of the gene is involved in a form of severe combined immunodeficiency. 